https://doi.org/10.46813/2022-137-085

\title{
HIGH-FIELD FORMING OF TUNGSTEN SURFACE BY EVAPORATION IN LIQUID NITROGEN
}

\author{
E.V. Sadanov, A.A. Mazilov, J.A. Gordienko, T.I. Mazilova, I.M. Mikhailovskij \\ National Science Center "Kharkov Institute of Physics and Technology”, Kharkiv, Ukraine \\ E-mail: alexey.mazilov@kipt.kharkov.ua
}

The basic obstacle to the application of the method of low-temperature field evaporation is the necessity of the creation of superhigh electric fields on the surface of the processing object. There are problems connected with the destruction of objects under the action of mechanical stress, generated by an electric field. In this contribution was shown that the phenomenon of high-field evaporation of metals in liquid nitrogen could be used for controlled forming of metal products with the sizes in a nanometer range used in modern nanotechnology. The evolution of microtopography was investigated by methods of field ion and electron microscopy and conventional methods of scanning electron microscopy. This contribution shows that as distinct from low-temperature evaporation in a high vacuum evaporation is observed here in a wide range of electric field strengths $4 \ldots .57 \mathrm{~V} / \mathrm{nm}$. In the proposed treatment process the mechanical stress of the electric field falls as low as $20 \mathrm{~kg} / \mathrm{mm}^{2}$. This value is less than the macroscopic strength by an order of magnitude.

PACS: 61.16.FK, 68.49.SF

\section{INTRODUCTION}

The phenomenon of field evaporation was used by authors earlier for forming the surface of the needle-like field emitters: electron emitters, ion emitters, and probe for scanning tunneling microscopes with high resolution [1-5]. It was demonstrated for the first time, that high field technology is the unique method, which provides, in particular, almost $100 \%$ use of emitters of multineedle cathodes. With the help of this technology for the first time in world nanotechnology, the atomic level of the emission localization at the probe surface was achieved [6]. But developed high-field nanotechnology of processing of a surface had important restrictions due to the necessity of application of super-high electrical fields.

Known standard methods of reception of a perfect surface with use of a ultra-high vacuum thermal processing and an ion bombardment are applicable only for flat monocrystal objects oriented along the closepacked crystallographic planes. In this contribution a physical basis of a method of the high-field processing of a metal surface was created, and the technology of manufacturing the nanoobjects of special purpose based on this phenomenon was developed. The solving of the problem of a mechanical stress reduction during the high-field formation process was delivered. The necessity to solve this problem is explained by severe technological conditions at the high voltage electrical fields which are producing the mechanical stress that above the strength limit of the metals and alloys that currently used by modern microsurgery and field emission nanotechnology $[1,2,7,8]$. Phenomenon of field evaporation stimulated by active gases is controlled by complex physical and chemical processes on the metal surface in high electric fields. In this report we described the main results on determination of physical characteristics of that phenomenon, which are important from technological point of view.

In connection with the qualitative novelty of the offer for development based on field evaporation of nanotechnology of manufacturing of microsurgical tools of new generation and emitters, it is necessary to solve several physical problems on the behavior metal in super-high electrical fields. Now the physical nature of the phenomenon of field evaporation in dielectric liquids is not completely understood. Application of this effect physics is in many degrees empirical. The analysis of literary sources on the kinetics of highmelting metal field evaporation stimulated by active gases $[1,2,9,10]$ has shown that nitrogen is one of the most efficient reagents. It permits a substantial reduction in the threshold value of evaporation field intensity. Accordingly, liquid nitrogen was selected as a dielectric fluid. In this paper, it was revealed an abnormally high nanotip etching rate in liquid nitrogen. These experiments have shown that the phenomenon of high field dielectric fluid surface formation takes place in electric fields with strengths substantially lower than those in high vacuum.

\section{INSTRUMENTS AND METHODS}

For field ion microscopic studies of surface conditions in the field treated samples two-chamber field ion microscopes (FIM) were used [1, 11]. The external chamber contains a cryogenic sorption pump in the form of a cylindrical Dewar vessel cooled with liquid nitrogen. Activated coal on the vessel surface is protected with a louver system from external chamber wall heat radiation. The lower part of the nitrogen vessel serves as a thermal screen for the second Dewar vessel with an internal cavity. An additional thermal screen is installed between both vessels.

Isolation is attained by diaphragm closure with the sample holder. The working chamber contains a high voltage input of fluoroplastic with a socket for sample holder, pulling electrode, and image brightness amplifier. In this design, the temperatures of samples and working chamber walls are identical and determined by the temperature of liquefied gases cooling the internal Dewar vessel. In case when solely nitrogen cooling is necessary, a removable sorbent cassette was inserted into the working chamber to create 
an acceptable vacuum (about $5 \cdot 10^{-7}$ Torr) in the chamber. The largest possible vacuum in the working chamber is attained when liquid helium or hydrogen are poured into the vessel. In this option, the best evacuation and insulation of internal and external chambers may be reached due to efficient freezing-out of gases incoming from the external chamber. Residual gas pressure will be $10^{-8} \ldots 10^{-9}$ Torr in this case. The gas in the feed system of the FIM was updated to perform treatments directly within the microscopes and deliberately create geometric peculiarities on the surface of tip samples. High voltage $(0 \sim 30 \mathrm{kV})$ is fed to the sample through HV vacuum input. Such inputs are used to feed microchannel plates.

At extremely low sample temperatures general resolution in the best image field is improved, but at the same time, the image at evaporating field deteriorates. To neutralize this effect and optically control field evaporation atom by atom, apart from DC $0 \ldots 25 \mathrm{kV}$ voltage a pulsed voltage may be applied to the sample with amplitude up to $30 \mathrm{kV}$. Pulsed voltage may be fed in both single and frequency modes when a sinusoidal $50 \mathrm{~Hz}$ AC voltage is superposed on the DC voltage. In this case, the ion image will even improve to some extent due to increased informativeness.

The sample in a microscope is replaced through a lock chamber with the help of a gliding piston. Vacuum condition is sufficiently quickly restored after this operation within $200 \mathrm{~s}$, the time necessary to cool sample holder up to working temperature. To install the holder (piston) to the socket while using various coolants the piston and socket must be highly coaxial. To this end, the internal part of the microscope is supported by a steel ball to make the structure fulcrum as close to the piston as possible. The upper part of the structure "floats" due to Dewar vessel pipes being introduced through bellows being differentially evacuated. To install the holder (piston) to the socket while using various coolants the piston and socket must be highly coaxial. To this end, the internal part of the microscope is supported by a steel ball to make the structure fulcrum as close to the piston as possible. The whole FIM vacuum system is first degassed by consecutive evacuation through a gate using auxiliary cryogenic pumps. A certain position of the gate allows to disconnect the auxiliary pumps from the chamber and to perform lockage of the sample under study. Pump evacuates only locking chamber. The microscope gas feeding system was updated to treat sample surface in active gases directly within the microscope chamber.

Initially, imaging gases were fed directly to the microscope external chamber. While using active gases easily evacuated by cryogenic pumps we managed to feed them directly to the working chamber through a thin capillary. In this case, the studies and sample treatment were performed only under dynamic gas feed. An exact adjustment of gas flow was attained due to the introduction of ballast volume $(\sim 21)$. A pulsed feed of gas to the working chamber also allowed the obtaining of certain surface structures using field nitrogen etching.

The high-field treatment in dielectric liquids was performed in all-glass open-ended Dewars and dielectric foamed plastic baths. The metallic counter-electrodes were made in the form of disc $10 \ldots 25 \mathrm{~mm}$ in diameter. The apex of treated tips in various experiments was placed at a distance of $5 \ldots 15 \mathrm{~mm}$ from the counterelectrode. The high-voltage supply unit $(0 \ldots 25 \mathrm{kV})$ is a one-half-period scheme of rectification and provides a quick change of voltage polarity on the specimen. The current limitation is executed with the resistor of $50 \mathrm{M} \Omega$ (maximum current $0.5 \mathrm{~mA}$ ) switching on. The photoand crystal luminescent $\mathrm{X}$-rays monitoring showed that the level of $\mathrm{X}$-radiation is rather admissible. The measuring of the high voltage delivered on the specimen was done with the usage of electrostatic kilovoltmeter C196. The stabilization of high voltage along the net was reached with the ferroresonance stabilizer. Microtips with a radius of curvature more than $50 \mathrm{~nm}$ were made by clamping with a vertical manipulator the specimen blank immersed a few millimeters into an electrolyte. This process was monitored by optical and electron microscopes, and analyzed by methods of computer simulation [1,12]. For the preparation of ultrafine tips, the floating-layer technique [1] was used.

\section{RESULTS AND DISCUSSION}

The analysis of literary sources on the kinetics of high-melting metal field evaporation as stimulated by active gases has shown that nitrogen is one of the most efficient reagents. It permits a substantial reduction in the threshold value of evaporation field intensity. Accordingly, liquid nitrogen was selected as a dielectric fluid. Our first experiments showed an abnormally high nanotip etching rate in liquid nitrogen. Fig. 1 shows the variation of axial symmetrical needle-type emitter curvature radius in the course of its high field treatment.

The initial tip radius as formed by field evaporation in vacuum at residual gas pressure $10^{-7}$ Torr was $6 \mathrm{~nm}$ (see Fig. 1,a). While being kept in liquid nitrogen at $1.2 \mathrm{kV}$ the tip was blunted within $8 \mathrm{~s}$, its radius increasing to $21 \mathrm{~nm}$. This substantially broke the regular surface arrangement of atoms (see Fig. 1,b).

Still, evaporation of two or three atomic layers partially reinstated regular atomic surface topography (see Fig. 1,c). Thus, this work shows that the application of $\mathrm{N}_{2}$ as cryogenic liquid permits the removal of a substantial amount of tip material, i.e., the ideal dielectric fluid behaves at high voltages and field intensities as an efficient electrolyte. At the same time, the configuration of tip apex after tungsten high voltage polishing in liquid nitrogen is substantially distinct from that obtained by field evaporation in high vacuum. For complete reinstatement of regular surface atomic arrangement, the sample apex should be evaporated to the depth of about 0.1 of curvature radius. Thus, the height of microtips as evaluated from ionic microscopy data is less than 0.1 of curvature radius. 


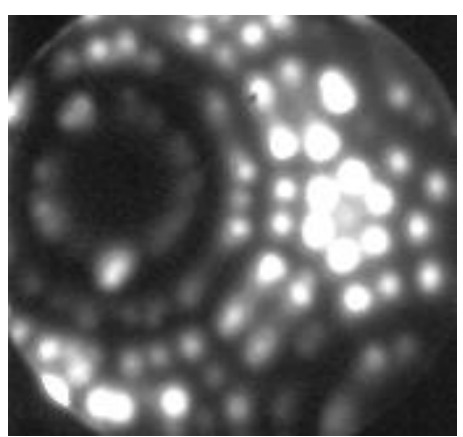

$a$

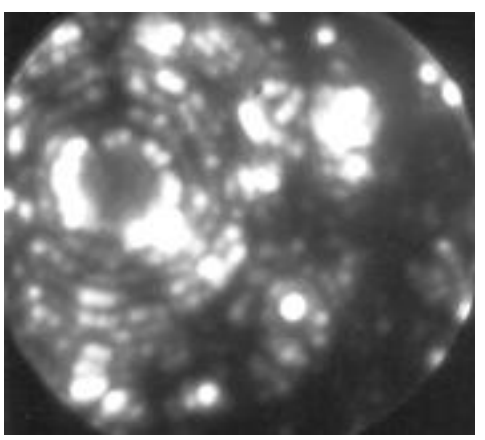

$b$

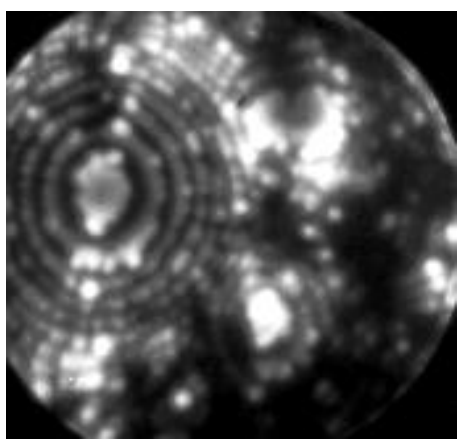

$c$

Fig. 1. Change in the radius of curvature $R$ of the emitter during its high-field processing. Initially $R=6 \mathrm{~nm}(\mathrm{a})$; after exposure in liquid nitrogen at a voltage of $1.2 \mathrm{kV}, R=21 \mathrm{~nm}(\mathrm{~b})$.

After evaporation of the surface layers, the atomic topography becomes regular $(c)$

Such an evaluation is valid only in cases when shapes of surfaces formed under high vacuum field evaporation and high field dielectric fluid treatment are similar at a mesoscopic level.

The height of topographic irregularities formed in the process of field evaporation remained unclear. In this connection electron microscope studies of the tip, apex geometry was performed. These experiments confirmed the data of the field ion microscopic studies that efficient evaporation is possible in dielectric media. An additional result was obtained from the analysis of surface microroughness in control experiments performed at Hahn-Meitner-Institut, Berlin. No signs of surface microroughness were seen in electronic micrograms with the magnification of about $\times 30000$ (Fig. 2). This is evident of the fact that surface roughness after a high-field treatment in liquid nitrogen never exceeds $1 \mathrm{~nm}$. Thus, in the general case, the roughness limit as evaluated from electronic micrograms was substantially less than 0.1 of the apex curvature radius, i.e. lower than the level evaluated by the method of controlled layer-by-layer field evaporation.

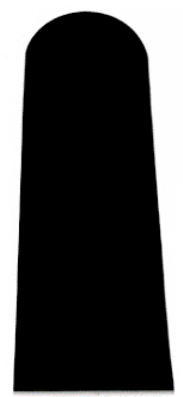

Fig. 2. Shadow electron microscopic image of a tungsten tip after high-field processing in liquid nitrogen, $\times 30000$

Apart from liquid nitrogen processing of tungsten samples, we tried similar experiments in isoamyl alcohol and carbon tetrachloride $\left(\mathrm{CCl}_{4}\right)$ which are liquid at room temperature and possess high ohmic resistance due to the low content of impurities and moisture. To this end, a special device was used with the cathode of stainless steel, whereas a $1 \ldots 5 \mathrm{kV}$ positive voltage was applied to the sample. The results of processing were evaluated by change of sample volt-ampere characteristics and based on ionic microscopy data. The effect was sufficiently well reproduced for various samples, still, the value of current reduction was different due to variation of samples initial geometry (taper angle). Similar conclusions of the total increase in sample curvature radius as a result of $\mathrm{CCl}_{4}$ treatment effected by electric field were made from ionic microscope studies. It should be noted that due to this treatment the sample takes a near-spherical shape provided there is an atomically uneven surface with large areas of structurally disordered material. Atomically even surface is preserved at pole output area $\{110\}$ where atom after atom evaporates. Field evaporation of the sample to remove structurally disordered material from the surface leads to the destruction of samples.

Surface observation by field electron microscopy (Fig. 3) has shown that according to the results of analysis of shade electron microscope images, after high-field treatment in liquid nitrogen no microtips substantially higher than a monoatomic can be seen on a surface formed by high field dielectric fluid treatment. The resolution of the image plane in a field electron microscope is less than $1 \mathrm{~nm}[1,2]$, but the resolution in a direction normal to the surface is close to the lattice parameter.

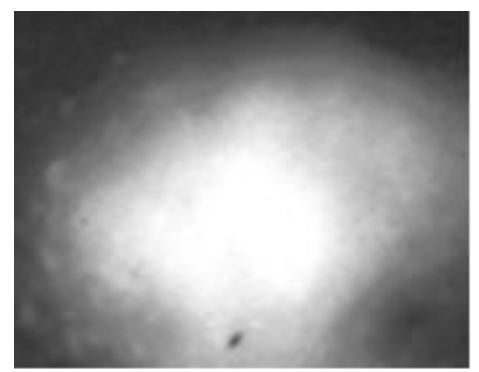

Fig. 3. A field electron image of a tungsten tip after high-field processing in liquid nitrogen

To define the threshold values of the field strength necessary for the high field dielectric liquids treatment the microtip dissolution kinetics was studied at various field intensities. In Fig. 4 the evaporation rate depends on field strength. As this study has shown, the rate of high field dielectric fluid treatment is independent of the variation of distance between electrodes within the range $5 \ldots 15 \mathrm{~mm}$. At the same time breakdown voltage under such circumstances rises from 6 to $15 \mathrm{kV}$. Thus, relatively large distances between electrodes may be recommended for surface formation. Evaporation rate was measured issuing from the variation of average curvature radius at known taper angle $\left(12 \ldots 14^{\circ}\right)$. 


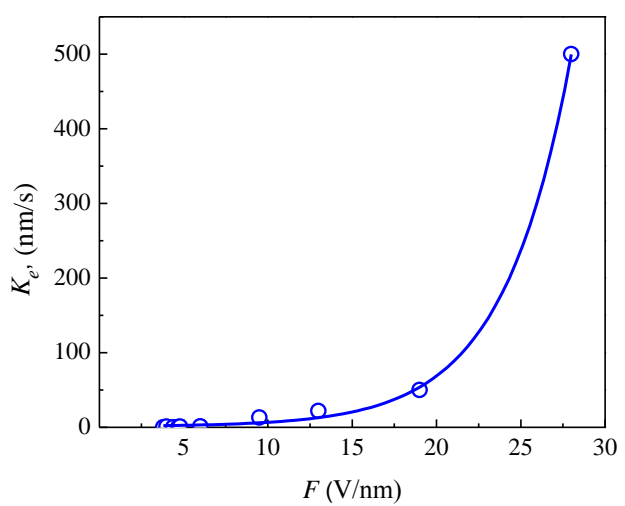

Fig. 4. Dependence of the rate of field evaporation of tungsten in liquid nitrogen on the strength of the electric field

The accuracy of such a method is evaluated to be about $50 \%$. Field strength was defined by comparing liquid nitrogen treatment voltage to tungsten evaporation threshold voltage in a high vacuum at $78 \mathrm{~K}$. In the latter case field intensity was reliably established to be $57 \mathrm{~V} / \mathrm{nm}[1,2]$. The accuracy of its determination was $15 \ldots 20 \%$ in various experiments. As we can see in Fig. 4, as distinct from low-temperature high vacuum evaporation [2], here evaporation is observed in a wide range of electric field strengths $5 \ldots 27 \mathrm{~V} / \mathrm{nm}$. Moreover, the range of evaporation intensities is much wider, namely $4 \ldots .57 \mathrm{~V} / \mathrm{nm}$. The plot does not show data on evaporation in the range $27 . .57 \mathrm{~V} / \mathrm{nm}$ due to abnormally high evaporation rates and large rate measurement error (above 50\%). Thus, our experiments have shown that the phenomenon of high field dielectric fluid surface formation takes place in electric fields with strengths lower than those in high vacuum by an order of magnitude. Accordingly, the density of ponderomotive forces is lower by two orders of magnitude. In the proposed treatment process the mechanical stress of the electric field falls as low as $20 \mathrm{~kg} / \mathrm{mm}^{2}$. This value is less than tungsten macroscopic ultimate strength by one order of magnitude. As a consequence, not a single mechanical damage of needle-form microcrystals under treatment has been found in the process.

\section{CONCLUSIONS}

A basic obstacle to the application of the method of low-temperature field evaporation is the necessity of the creation of superhigh electric fields on the surface of the processing object. In such fields, there are serious technical problems connected with the destruction of objects under the action of mechanical stress, generated by an electric field. In this contribution was shown that the phenomenon of high-field evaporation of metals in dielectric liquids could be used for controlled forming of metal products with the sizes in a nanometer range used in modern nanotechnology. A mode of the polishing phenomenon of high-field treatment of metals in dielectric liquids results in the formation of a surface with a nearly monoatomic microroughness. That causes technological prospects of application of this phenomenon.
The phenomenon of high field surface formation in dielectric liquids takes place in electric fields with strengths lower than those in high vacuum by an order of magnitude. Accordingly, the density of ponderomotive forces is lower by two orders of magnitude. In the proposed treatment process the mechanical stress of the electric field falls as low as $20 \mathrm{~kg} / \mathrm{mm}^{2}$. This value is less than tungsten macroscopic ultimate strength by one order of magnitude. As a consequence, not a single mechanical damage of needle-form microcrystals under the treatment has been found.

\section{REFERENCES}

1. M.K. Miller, L. Cerezo, M.G. Hetherington, G.D.W. Smith. Atom Probe Ion Microscopy. Oxford: "Clarendon Press", 1996.

2. E.W. Muller, T.T. Tsong. Field Ion Microscopy. N.Y.: “American Elsevier Publishing Company", 1969, $14 \mathrm{p}$.

3. Patent 25020 Ukraine, IPC A 61B 17/32. Microsurgical cutting instrument / O.A. Velikodnaja, T.A. Ignatjeva, I.M. Mikhailovskij (UA); NSC "Kharkov Institute of Physics and Technology"; Appl. 21.12.1994; Publ. 25.12.1998; Bull. N 6, 8 p.

4. Patent 2271 Belarus, IPC A 61B 17/32. Microsurgical cutting instrument / O.A. Velikodnaja, T.A. Ignatjeva, I.M. Mikhailovskij (UA); NSC "Kharkov Institute of Physics and Technology"; Appl. 04.07.1995; Publ. 30.09.1998; Bull. N 6, 3 p.

5. Patent 40257 Ukraine, IPC A 61B 17/32. Cutting microsurgical instrument / N. Wanderka, T.I. Mazilova, I.M. Mikhailovskij (UA); NSC "Kharkov Institute of Physics and Technology"; Appl. 03.11.00; Publ. 16.07.01; Bull. N 6, 3 p.

6. M.K. Miller and R.G. Forbes. Atom-Probe Tomography. Springer, Boston, MA, 2014, p. 111-187.

7. O.V. Dudka, V.A. Ksenofontov, A.A. Mazilov, T.I. Mazilova, E.V. Sadanov, I.M. Mikhailovskij. Surface diffusion of tungsten adatoms induced by lowenergy bombardment with He atoms // Radiation Effects and Defects in Solids. 2016, v. 171, N 7-8, p. 606-614.

8. S.A. Kotrechko, A.A. Mazilov, T.I. Mazilova, E.V.Sadanov, I.M. Mikhailovskij. Experimental determination of the mechanical strength of monatomic carbon chains // Technical Physics Letters. 2012, v. 38, N 2, p. 132-134.

9. R.G. Forbes, E.I. Lugovskaja, A.V. Mazilov, T.I. Mazilova, I.M. Mikhailovskij. UA Patent No. 66,188 A, 15 Aug. 2006.

10. M.K. Miller and R.G. Forbes. Introduction to the Physics of Field Ion Emitters // Atom-Probe Tomography. Springer, Boston, MA, 2014, p. 51-109.

11. E.V. Sadanov, T.I. Mazilova, I.M. Mikhailovskij, V.A. Ksenofontov, A.A. Mazilov. Field-ion imaging of nano-objects at far-subangstrom resolution // Physical Review B. 2011, v. 84, N 3, p. 035429.

12. I.M. Mikhailovskij, N. Wanderka, T.I. Mazilova, V.A. Ksenofontov, E.V. Sadanov, A.A. Mazilov. The $\omega$ structure of the lateral twin boundary in tungsten // Philosophical Magazine Letters. 2007, v. 87, N 10, p. 743-750.

Article received 18.10.2021 


\section{ВЫСОКОПОЛЕВОЕ ФОРМИРОВАНИЕ ПОВЕРХНОСТИ ВОЛЬФРАМА ИСПАРЕНИЕМ В ЖИДКОМ АЗОТЕ}

\section{Е.В. Саданов, А.А. Мазилов, Ю.А. Гордиенко, Т.И. Мазилова, И.М. Михайловский}

Существенной преградой в применении метода низкотемпературного полевого испарения является необходимость создания сверхсильных электрических полей на поверхности обрабатываемого объекта. В таких полях возникают проблемы, связанные с разрушением объектов под воздействием механических напряжений, создаваемых электрическим полем. В этой работе было показано, что явление высокополевого испарения металлов в жидком азоте может быть использовано для контролируемого формоизменения металлических изделий с размерами в нанометровом диапазоне, которые применяются в современной нанотехнологии. Эволюция микротопографии была исследована методами полевой ионной и электронной микроскопии и традиционными методами сканирующей электронной микроскопии. Показано, что в отличие от низкотемпературного полевого испарения в высоком вакууме, эффект наблюдается в широком интервале напряженностей поля - 4..57 В/нм. В этом случае механические напряжения электрического поля

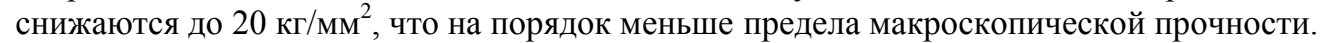

\section{ВИСОКОПОЛЬОВЕ ФОРМУВАННЯ ПОВЕРХНІ ВОЛЬФРАМУ ВИПАРОВУВАННЯМ У РІДКОМУ АЗОТІ}

\section{С.В. Саданов, О.О. Мазілов, Ю.О. Гордієнко, Т.І. Мазілова, І.М. Михайловський}

Суттєвою перепоною в застосуванні методу низькотемпературного польового випарування $\epsilon$ необхідність створення надсильних електричних полів на поверхні об'єкта, що оброблюється. У таких полях виникають проблеми, пов'язані з руйнуванням об'єктів під дією механічних напружень, які створюються електричним полем. У цій роботі було показано, що явище високопольового випаровування металів у рідкому азоті може бути використано для контрольованого формозмінення металевих виробів з розмірами в нанометровому діапазоні, які застосовуються в сучасній нанотехнології. Еволюцію мікротопографії було досліджено методами польової іонної та електронної мікроскопії і традиційними методами скануючої електронної мікроскопії. Показано, що на відміну від польового випаровування у високому вакуумі, ефект спостерігається в широкому інтервалі напруженостей поля - 4..57 В/нм. У цьому разі механічні

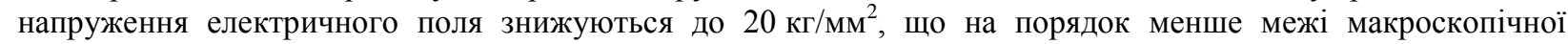
міцності. 